J. Dairy Sci. 99:1773-1779

http://dx.doi.org/10.3168/jds.2015-9919

(C) American Dairy Science Association ${ }^{\circledR}, 2016$.

\title{
Development of a colloidal gold immunochromatographic strip assay for simple and fast detection of human a-lactalbumin in genetically modified cow milk
}

\author{
Chenyu Tao,, Qingde Zhang, $†$ Na Feng, ${ }^{*}$ Deshi Shi, $†$ and Bang Liu*1 \\ *Key Lab of Agricultural Animal Genetics, Breeding, and Reproduction of Ministry of Education \& Key Lab of Swine Genetics \\ and Breeding of Ministry of Agriculture, and \\ †College of Veterinary Medicine, Huazhong Agricultural University, Wuhan 430070, Hubei, PR China
}

\begin{abstract}
The qualitative and quantitative declaration of food ingredients is important to consumers, especially for genetically modified food as it experiences a rapid increase in sales. In this study, we designed an accurate and rapid detection system using colloidal gold immunochromatographic strip assay (GICA) methods to detect genetically modified cow milk. First, we prepared 2 monoclonal antibodies for human $\alpha$-lactalbumin $(\alpha-$ LA) and measured their antibody titers; the one with the higher titer was used for further experiments. Then, we found the optimal $\mathrm{pH}$ value and protein amount of GICA for detection of pure milk samples. The developed strips successfully detected genetically modified cow milk and non-modified cow milk. To determine the sensitivity of GICA, a quantitative ELISA system was used to determine the exact amount of $\alpha-L A$, and then genetically modified milk was diluted at different rates to test the sensitivity of GICA; the sensitivity was $10 \mu \mathrm{g} / \mathrm{mL}$. Our results demonstrated that the applied method was effective to detect human $\alpha$-LA in cow milk.
\end{abstract}

Key words: genetically modified cow milk, ELISA, colloidal gold immunochromatographic strip assay, human $\alpha$-lactalbumin

\section{INTRODUCTION}

Cow milk provides various nutrients for human health and thus plays a very important role in the daily life of humans. However, great composition differences between cow milk and human milk have made it necessary to make cow milk more like the composition of human milk to meet the nutritional requirements of infants and some adults. For example, in cow milk, the

Received June 7, 2015.

Accepted October 20, 2015.

${ }^{1}$ Corresponding author: liubang@mail.hzau.edu.cn ratio of casein to whey protein is about $80: 20$ (wt/wt), whereas in human milk it is 40:60 (wt/wt; Lien, 2003).

One of the key whey proteins in milk is $\alpha$-LA, a small (relative molecular mass of 14,200), acidic (isoelectric point of 4.5), and $\mathrm{Ca}^{2+}$-binding milk protein, which is very important from a nutritional and physiological point of view (Permyakov and Berliner, 2000). $\alpha$-Lactalbumin contains 63\% EAA, particularly tryptophan, the precursor of serotonin involved in nervous system activities such as mood regulation and cognitive function (Booij et al., 2006), and also a high percentage of branched-chain AA, such as isoleucine and leucine, which are related to protein synthesis in muscle (Layman, 2003). From a physiological viewpoint, $\alpha$-LA binds to galactosyl transferase only in the presence of substrates and modifies its specificity. In addition, different fold changes in human $\alpha$-LA can lead to tumor cell apoptosis (Svensson et al., 2000), suggesting that this folding variant might be a potential antitumor drug.

Despite the importance of $\alpha$-LA in human health, the amount of this protein in cow milk is about 2 to $5 \%$ of the total protein, far less than that in the human milk (25-35\% of the total amount, about $2.44 \pm 0.64 \mathrm{~g} / \mathrm{L}$; Jackson et al., 2004). Thus, scientists have tried many different methods to improve the content of $\alpha$-LA in cow milk. Until now, the best way to solve this problem has been the transgenic approach. In the past few years, several mammary gland bioreactors have been successfully developed for protein production. In 2008, genetically modified cattle with recombined human $\alpha$-LA were successfully cloned at China Agricultural University; genetic modification in the cattle using somatic cell nuclear transfer significantly improved its nutritional value (Wang et al., 2008).

Currently, biotechnology products are subject to a very strict system of safety assessment and production monitoring, which is mainly performed using reliable and sensitive detection approaches. The detection methods that are most frequently used focus on the 
detection of DNA or protein levels, such as PCR, Southern blot, and loop-mediated isothermal amplification for DNA-level detection and ELISA, Western blot, and colloidal gold immunochromatography assay (GICA) for protein-level detection. However, some detection methods are time-consuming, need expensive instruments, and are not suitable for field testing, and, as such, there is a shortage of reliable, fast, and convenient methods. In 2012, Zhai et al. (2012) introduced loop-mediated isothermal amplification for genetically modified animal detection for the first time and successfully established a reliable and rapid system for detecting human lactotransferrin and human $\alpha$-LA genetically modified cows, with detection results observable with the naked eye. Thereafter, several related studies were carried out using the same method (Tao et al., 2013). Liu et al. (2013) proved that Western blot, SDS-PAGE, ELISA, and GICA methods are efficient for the detection of human lactotransferrin protein in genetically modified cow milk; among those methods, immunochromatographic strips were considered to be the most effective and convenient for field inspection due to the advantage of needing no help from professional technicians or extra equipment.

Colloidal gold immunochromatography assay is a test method that moves the sample along a test strip. This type of assay is portable, convenient, presents easily identifiable results, and is capable of delivering reliable results within 3 to 5 min without the use of any expensive laboratory equipment. In the past decade it has been widely applied in the detection of bacteria, viruses, hormones, and some small-molecule drugs (Stephan et al., 2002). Based on a working principle, the GICA method can be divided into competitive-type and sandwich-type assays. The principle of this method will not be described in detail here due to the limit of space. The aim of the present study was to report the construction of a rapid and convenient protocol that could be further applied in the detection of more transgenic animals by using competitive GICA to detect human $\alpha$-LA in genetically modified cow milk and sheep milk or goat milk.

\section{MATERIALS AND METHODS}

\section{Collection of Milk Samples and Other Experimental Materials}

The genetically modified (GM) milk collected from 3 human $\alpha$-LA genetically modified cows was provided by the State Key Laboratory for Agrobiotechnology from China Agricultural University (Beijing, China) and stored at $-80^{\circ} \mathrm{C}$. Fresh non-GM milk used as negative control was bought from the local market (total protein percentage $=3.2 \mathrm{~g} / 100 \mathrm{~g} ;$ Mengniu Company, Hohhot, PR China).

Human o-LA protein (L7296; Sigma Aldrich, St. Louis, MO) was purchased as a positive control; the IsoQuick Kit for Mouse Monoclonal Isotyping (ISOQ51KT; Sigma Aldrich) was also used. The nitrocellulose membrane, sample pad, and absorbent pad for GICA were obtained from Millipore (Billerica, MA).

\section{Monoclonal Antibody Preparation of Human $\alpha-L A$}

Two BALB/C mice were immunized by injection of human $\alpha-\mathrm{LA}$; then, after estimation of serum antibody titer, spleen cells were taken out and fused with mouse myeloma cell SP2/0. Next, constant screening was applied for the fusion cells with HAT (hypoxanthine, aminopterin, and thymidine) cell culture; after 4 cell antibody titer tests of cell culture supernatant, the fusion cells were selected for further incubation. The 2 monoclonal antibodies (mAb; 3A9, 3D2) were purified from the ascites of hybridoma cells of 2 mice injected with the fusion cells.

\section{Estimation of Subtype and Titer of the mAb}

The subtypes of the 2 anti- $\alpha-\mathrm{LA}$ mAb (3A9 and 3D2) were tested with the IsoQuick Kit for Mouse Monoclonal Isotyping according to the instructions. The $\mathrm{mAb}$ titer was estimated using the ELISA method. The ELISA plate was incubated with $100 \mu \mathrm{L}$ of human $\alpha$-LA $(4 \mu \mathrm{L} / \mathrm{mg})$ at $4^{\circ} \mathrm{C}$ overnight, followed by blocking the coated plate with $1 \%$ BSA and $0.05 \%$ Tween-20 solution (Sigma Aldrich) and incubation with mAb (dilution rate $=100,500,1,000,5,000,10,000$, and 50,000) for $1 \mathrm{~h}$ and secondary antibody goat anti-mouse IgG (1:4,000 dilution) for $30 \mathrm{~min}$. The highest amount of secondary antibody was tested and was detailed in the Supplementary Materials (http://dx.doi.org/10.3168/ jds.2015-9919). Subsequently, the as-treated plate was supplemented with substrate $(100 \mu \mathrm{L})$ and $50 \mu \mathrm{L}$ of stop solution. The absorbance at $450 \mathrm{~nm}$ was read with an UV spectrophotometer and the higher titer antibody was selected for the next experiment.

\section{GICA}

Colloidal gold is the colloidal suspension of submicrometer-sized nanoparticles of gold in a fluid that can be prepared by several different methods, among which the sodium citrate reduction method (Frens,1973) was frequently used because the size of colloidal gold particles could be controlled by the choice of reductant (De Roe, et al., 1987). Two hundred milliliters of 
Table 1. The absorbance of the immunized mice sera at different dilutions ${ }^{1}$

\begin{tabular}{lcccccccc}
\hline Mouse & $1: 1,000$ & $1: 3,000$ & $1: 9,000$ & $1: 27,000$ & $1: 81,000$ & $1: 240,000$ & $1: 720,000$ & PBS \\
\hline 1 & 2.844 & 1.516 & 0.68 & 0.32 & 0.171 & 0.101 & 0.072 \\
2 & 3.411 & 2.004 & 0.939 & 0.528 & 0.285 & 0.14 & 0.075 \\
\hline
\end{tabular}

${ }^{1}$ The ratios represent the serum dilution of the 2 antibody titers, whereas numbers 1 and 2 represent the 2 immunized mice.

ultrapure water was constantly heated and vortexed until boiling, followed by adding $2 \mathrm{~mL}$ of chloroauric acid $\left(\mathrm{HAuCl}_{4} \cdot 3 \mathrm{H}_{2} \mathrm{O}\right.$; terminal concentration $\left.=0.01 \%\right)$ and $3.6 \mathrm{~mL}$ of $1 \%$ trisodium citrate until the solution turned a wine-red color.

Considering the importance of protein and $\mathrm{pH}$ in the conjunction of colloidal gold and protein complex, we optimized the $\mathrm{pH}$ value and the protein amount. After the colloidal gold cooled to room temperature, the $\mathrm{pH}$ and protein were adjusted by adding $10 \mu \mathrm{L}$ of $0.01 \mathrm{M}$ $\mathrm{K}_{2} \mathrm{CO}_{3}$ and $6 \mu \mathrm{g}$ of human $\alpha$-LA protein to $1 \mathrm{~mL}$ of colloidal gold solution. Subsequently, $1.24 \mathrm{~mL}$ of $10 \%$ BSA solution was added and mixed to block the excess reactive sites of the gold. Finally, the human $\alpha$-LA-linked gold was centrifuged at $2,000 \times g$ and $4^{\circ} \mathrm{C}$ for $30 \mathrm{~min}$, followed by removing the supernatant and suspending the resulting pellets in $1 \mathrm{~mL}$ of borax buffer.

Conjugate pads were treated with blocking buffer containing $2 \%$ BSA, $2.5 \%$ sucrose, $0.3 \%$ polyvinylpyrrolidone K30, and $0.02 \%$ sodium azide. The gold-mAb was sprayed onto the blocked conjugate pads, which were immediately lyophilized. At the test line (T line), the human $\alpha$-LA was diluted to $1 \mathrm{mg} / \mathrm{mL}$ in PBS solution containing $6 \%$ methanol and spotted onto the nitrocellulose membrane; at the control line (C line), the secondary antibody (IgG) was spotted using a ZX1000 Dispensing Platform (BioDot, Irvine, CA), followed by drying the membrane at $37^{\circ} \mathrm{C}$ for $30 \mathrm{~min}$. Finally, all the components of the strip were laminated on a sheet with plastic backing, including the sample pad, the conjugate pad, nitrocellulose membrane, and the absorbent pad.

\section{Specificity and Sensitivity of GICA}

The GM milk concentration used in our study was determined by ELISA. The standard sample of human $\alpha$-LA was 1:5 diluted, which was used to incubate the plate as well as the defatted and diluted genetically modified milk [09023(3), 8224, 071223] contained in the same plate. According to the recommended amount of $\mathrm{mAb}$ and secondary antibody and the ELISA protocol, the absorbance was measured at $450 \mathrm{~nm}$ via UV spectrophotometer.

To test the specificity of these strips, the sample pads were immersed in PBS and human $\alpha$-LA protein solu- tion, and to determine the sensitivity the human $\alpha$-LA GM milk samples were diluted 500, 200, 100, 50, and 0 times. The detection was based on the appearance of $\mathrm{T}$ line or $\mathrm{C}$ line. With the appearance of the $\mathrm{T}$ line, the samples were judged to be negative, with the disappearance of the $\mathrm{T}$ line, the samples were determined to be positive, and with the disappearance of the $\mathrm{C}$ line, the strips were expired and the detection results were invalid.

\section{Detection of Milk Samples by Developed Strips}

The sample pads were immersed in defatted and diluted human $\alpha$-LA GM milk samples of 09023(3), 8224, and $071223 ; 5$ min later the changes of the strips were observed.

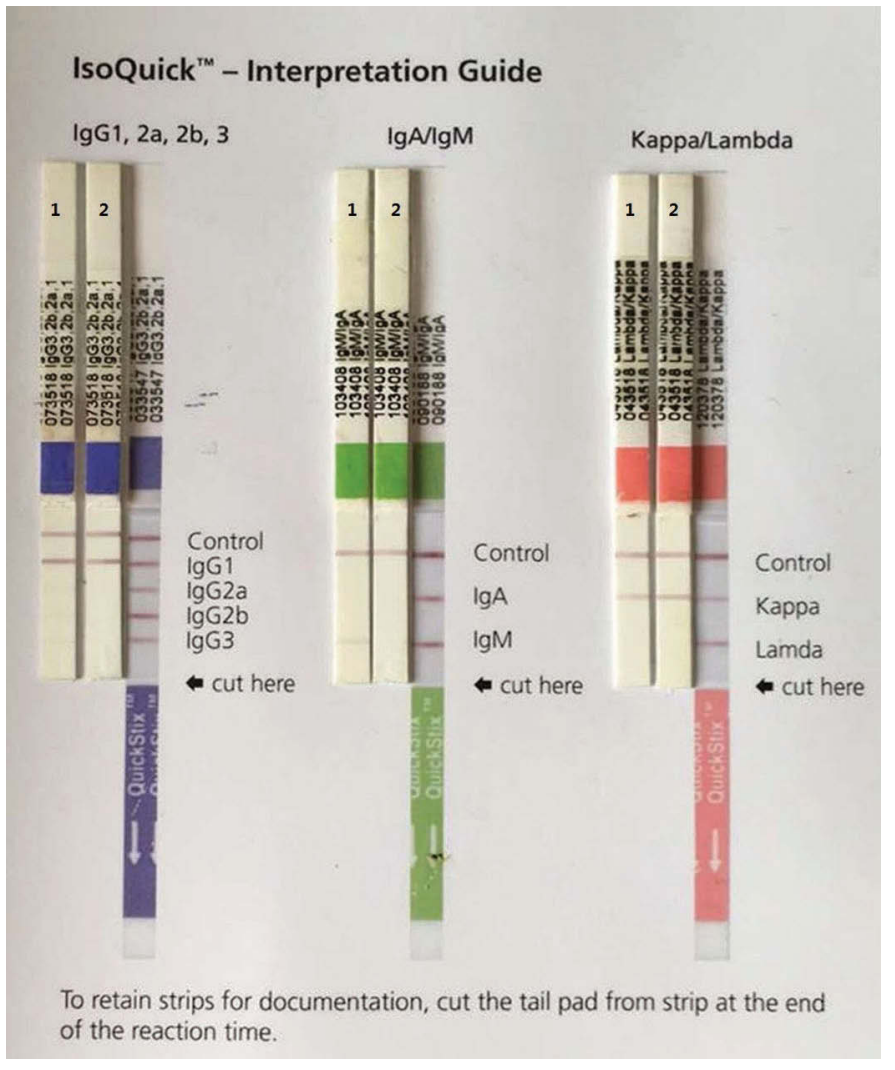

Figure 1. Determination of the subtypes of monoclonal antibody (mAb) 3A9 (1) and 3D2 (2). Color version available online. 


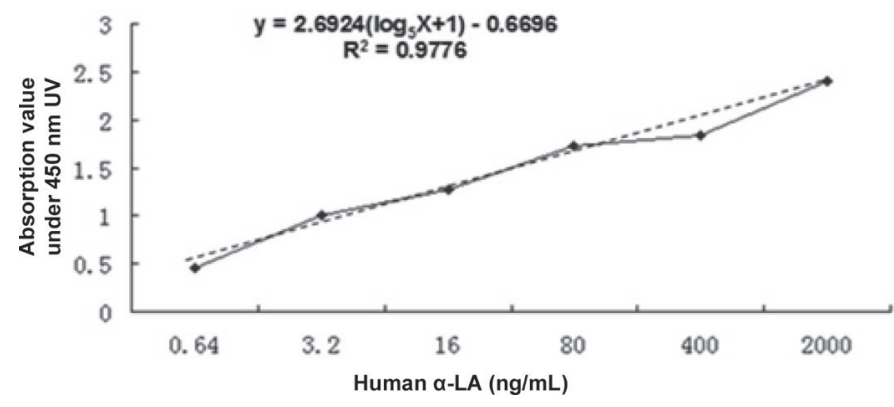

Figure 2. Human $\alpha$-LA protein detected with ELISA.

\section{RESULTS AND DISCUSSION}

\section{Monoclonal Antibody Preparation of Human $\alpha-L A$}

After 4 immunizations by the mixture of human $\alpha$-LA $(1 \mathrm{mg} / \mathrm{mL})$ and adjuvant, a blood test was performed on the 2 mice to confirm the serum antibody titer using the ELISA method. The absorbance was measured at $450 \mathrm{~nm}$ via spectrophotometer, and results are listed in Table 1 . The results indicated that the serum antibody titer value of mouse \#2 was greater than that of mouse \#1; thus, mouse \#1 was selected for the preparation of the hybridoma cell.
Table 2. Detection of human $\alpha$-LA content in genetically modified milk

\begin{tabular}{lc}
\hline Sample no. & Concentration $(\mathrm{mg} / \mathrm{mL})$ \\
\hline $09023(3)$ & 0.9 \\
8224 & 1.099 \\
071223 & 1.508 \\
\hline
\end{tabular}

\section{Estimation of Subtype and Titer of the mAb}

The subtypes of the 2 anti- $\alpha \mathrm{LA}$ mAb (3A9 and 3A2) were tested by IsoQuick Kit for Mouse Monoclonal Isotyping according to the instructions. As shown in Figure 1 , the subtypes of both $\mathrm{mAb}$ were IgG, the heavy chain was IgG1, and the light chain was kappa. The clear single band indicated that the obtained $\mathrm{mAb}$ had high specificity and could be used for further experiments.

The mAb titer was estimated by using the ELISA method. The dilution rate corresponded to the absorbance measured at $450 \mathrm{~nm}$ via spectrophotometer and the titer of the mAb was equal to or greater than 1.0. The results obtained using this method showed that the titer of mAb 3A9 was $1: 10,000$ and 3D2 was 1:5,000, indicating that the $2 \mathrm{mAb}$ were high-titer antibodies and met the standard of antibody titer for immunological experiments. Due to a higher antibody titer than 3D2, 3A9 was used for further experiments.

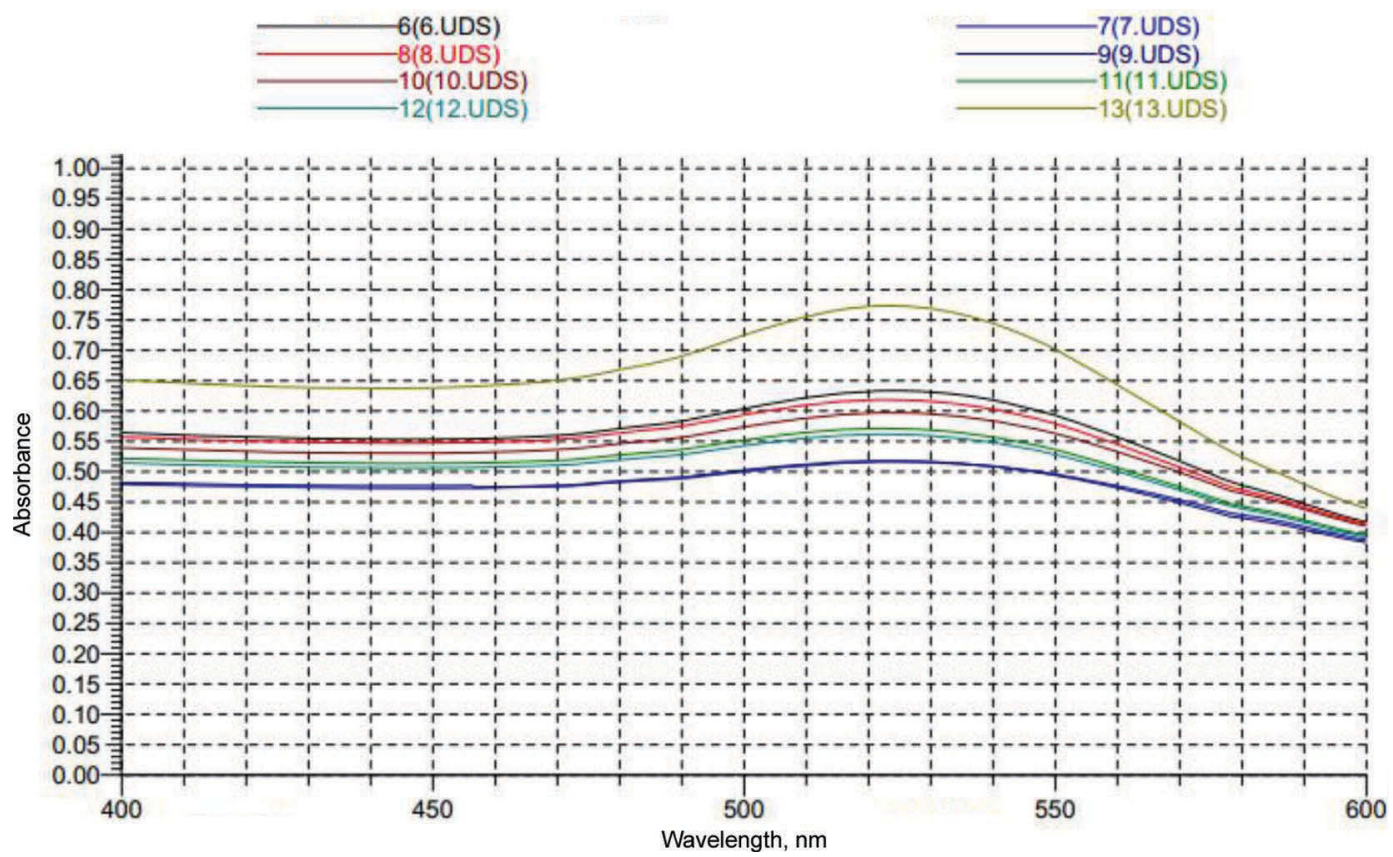

Figure 3. Optimization of $\mathrm{pH}$ for conjunction of human $\alpha-\mathrm{LA}$ and colloidal gold. Each line in a different color represents the absorbance, plotted by different wavelengths on the horizontal axis and absorbance on the vertical. 


\section{Determination of Human $\alpha-L A$ in GM Milk}

First, we tested the range of ELISA method in detecting human $\alpha$-LA (see Supplementary Figures S1 and S2; http://dx.doi.org/10.3168/jds.2015-9919). Then we selected some concentrations within the ELISA range $(0.64,3.2,16,80$, and $400 \mathrm{ng} / \mathrm{mL})$ to obtain an accurate linear relationship and a linear relationship formula was developed (Figure 2). Next, we entered the absorbance values of the defatted and diluted GM milk into the formula to calculate the concentrations of human $\alpha$-LA in GM milk (Table 2). The content values of human $\alpha$-LA in these 3 GM cow milks were compared with those in other GM milks, and the values were about an order of magnitude higher, which validated our results (Wang et al., 2008).

\section{Optimization of $\mathrm{pH}$ and Human $\alpha$-LA Amount}

The $\mathrm{pH}$ value and protein amount were optimized in our study; different amounts of $\mathrm{K}_{2} \mathrm{CO}_{3}\left(\begin{array}{ll}0.01 & M\end{array}\right)$ represent different $\mathrm{pH}$ values. For example, if $10 \mu \mathrm{L}$ of $\mathrm{K}_{2} \mathrm{CO}_{3}(0.01 \mathrm{M})$ was added to $1 \mathrm{~mL}$ of colloidal gold solution, the $\mathrm{pH}$ of the solution was 10 . Based on this principle, we added 6 to $13 \mu \mathrm{L}$ of $\mathrm{K}_{2} \mathrm{CO}_{3}(0.01 M)$ into the solution and measured the absorbance at $450 \mathrm{~nm}$ via spectrophotometer. The results are shown in Figure 3 , and indicate that the maximum absorbance peak occurred at $\mathrm{pH}$ 13. Thus, the best $\mathrm{pH}$ for the binding of human $\alpha$-LA to colloidal gold is 13 .

The amount of human $\alpha$-LA protein in conjunction with colloidal gold was also optimized. Eight different amounts of $1 \mathrm{mg} / \mathrm{mL}$ of human $\alpha$-LA $(0$ to $7 \mu \mathrm{L})$, which were marked 1-8 in Figure 4, were added separately into $1 \mathrm{~mL}$ of colloidal gold solution $(\mathrm{pH}=13)$, and the absorbances were measured at $450 \mathrm{~nm}$ via UV spectrophotometer. From the maximum absorbance peak (Figure 4A), we found the optimum amount for this reaction was $6 \mu \mathrm{g}$, which was consistent with the color change results in Figure 4B. The color of the solution in tube 7 in Figure 4B is the closest to the color of the common colloidal gold solution; thus, the optimized amount of human $\alpha$-LA was $6 \mu \mathrm{g}$.

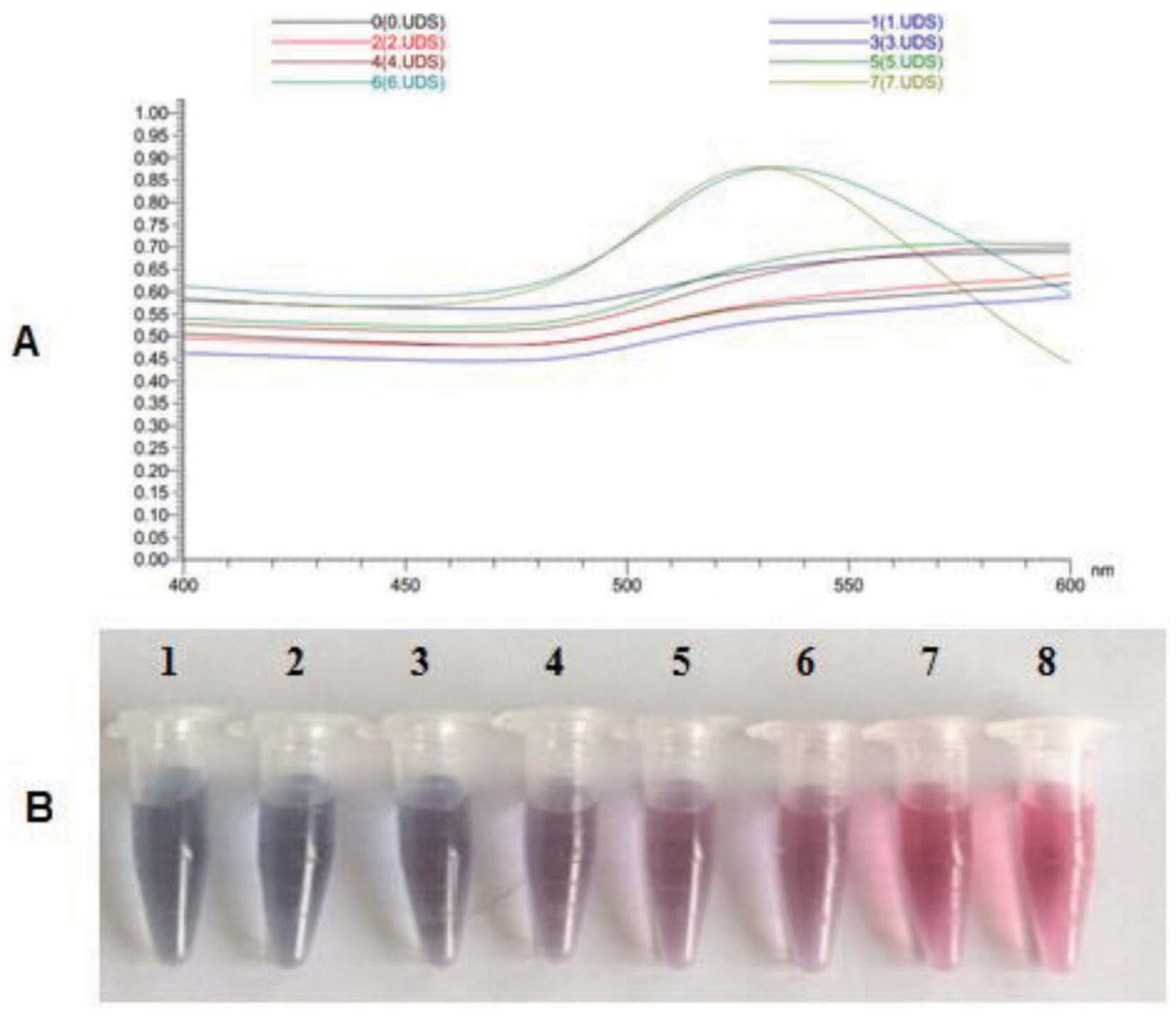

Figure 4. Optimization of human $\alpha$-LA amount in conjunction with colloidal gold. 


\section{Performance Tests of the Colloidal Gold Immunochromatographic Strips}

After assembling, the strips were immersed in $100 \mu \mathrm{L}$ of solution samples, and 5 min later the results could be observed on the strips (Figure 5). Figure 5A shows the result of preliminary tests of the strips. The $\mathrm{C}$ line appeared on the 2 strips testing PBS and human $\alpha$-LA protein standard solution, which indicated the strips were effective. The $\mathrm{T}$ line appeared on the first strip but not on the second strip, which illustrated the correct result of competitive immunochromatography strips. Figure 5B shows the result of GM milk detection. The first strip was PBS, strip 2 was non-GM cow milk, and strips 3,4 , and 5 were GM milk. All these strips were effective because of the appearance of $\mathrm{C}$ line. Strips 1 and 2 showed negative results and strips 3 to 5 for genetically modified milk also showed negative results. The results indicated that the colloidal gold immunochromatographic strips were reliable and efficient.

The strips were also tested for the lowest concentration at which $\mathrm{T}$ line was completely absent. The genetically modified milk was diluted at different rates $(500,200,100,50$, and 0$)$ and then the strips were used to test them (Figure 6). The $\mathrm{C}$ line appeared on all the strips, which illustrated the validity of the strips. The $\mathrm{T}$ line appeared clearly on strips 1 to 3 but not on strips 4 to 7 , indicating the sensitivity of this reac-



A

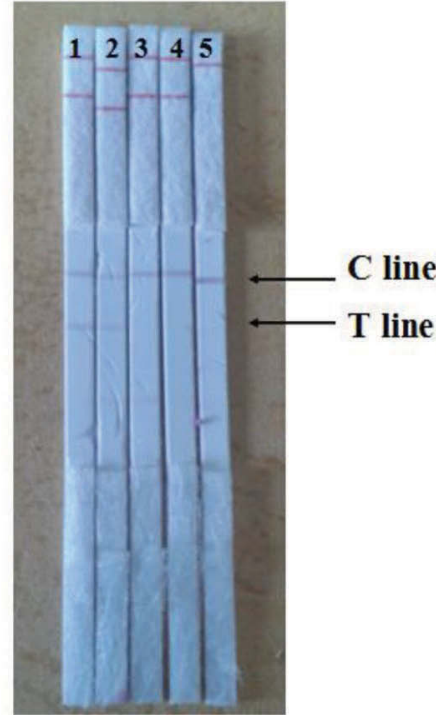

B
Figure 5. Performance tests of the colloidal gold immunochromatographic strips. (A) Preliminary tests of the strips $(1=$ PBS; $2=$ $1 \mathrm{mg} / \mathrm{mL}$ of human $\alpha$-LA protein standard solution). (B) Detection of genetically modified milk $[1=\mathrm{PBS} ; 2=$ non-genetically modified cow milk; 3,4 , and $5=$ genetically modified milk 09023(3), 8224, 071223]. $\mathrm{C}$ line $=$ control line; $\mathrm{T}$ line $=$ test line. Color version available online.

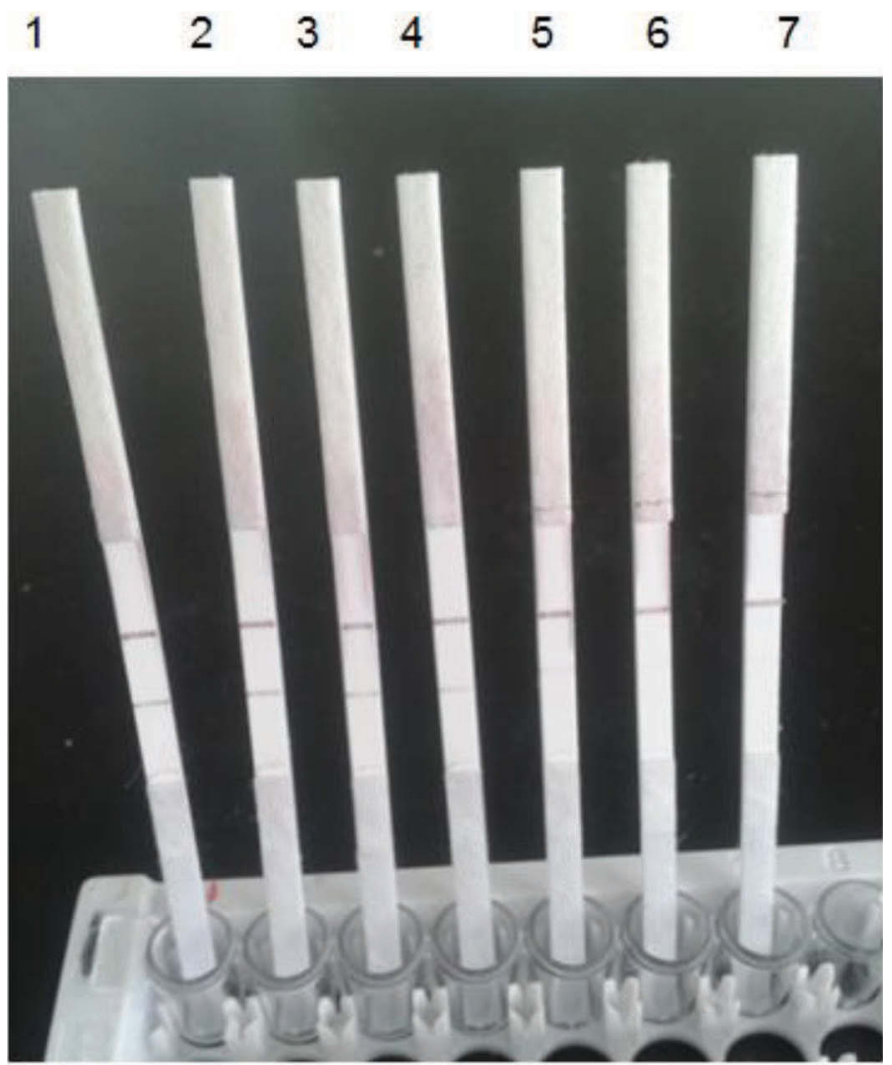

Figure 6. Sensitivity of the colloidal gold immunochromatographic strips. $1=$ PBS; $2-6=$ genetically modified milk diluted 500, 200, 100, 50 , and 0 times, respectively; $7=1 \mathrm{mg} / \mathrm{mL}$ of human $\alpha$-LA protein standard solution. Color version available online.

tion system was 100 times diluted GM milk. Based on the ELISA result, the amount of human $\alpha$-LA protein was about $1 \mathrm{mg} / \mathrm{mL}$ (Table 2), suggesting that the sensitivity of this reaction system was about $10 \mu \mathrm{g} / \mathrm{mL}$, whereas the sensitivity of ELISA detecting $\alpha$-LA was as low as $0.128 \mathrm{ng} / \mathrm{mL}$. Therefore, the ELISA method can quantitatively detect protein amount, whereas GICA can semiquantitatively detect the target protein.

The strip was not as sensitive as expected, perhaps because of the limitation of competitive types. The inhibition of the $\mathrm{T}$ line relied on the mass of human $\alpha$-LA protein molecules, and only when the human $\alpha$-LA exceeded the coated human $\alpha$-LA at the T line or the dissociative human $\alpha$-LA in the sample could absolute inhibition occur.

\section{ACKNOWLEDGMENTS}

We are grateful to the State Key Laboratory for Agribiotechnology from China Agricultural University for providing the transgenic milk samples. We also appreciate the help of Zhu Hanchang (Huazhong Agricultural University, Wuhan, PR China) in language editing. 
This work was supported by the National Transgenic Project of China (2009ZX08012-015B).

\section{REFERENCES}

Booij, L., W. Merens, C. R. Markus, and A. J. Van der Does. 2006. Diet rich in $\alpha$-lactalbumin improves memory in unmedicated recovered depressed patients and matched controls. J. Psychopharmacol. 20:526-535.

De Roe, C., P. J. Courtoy, and P. Baudhuin. 1987. A model of proteincolloidal gold interactions. J. Histochem. Cytochem. 35:1191-1198.

Frens, G. 1973. Controlled nucleation for the regulation of particle size in monodisperse gold solutions. Nat. Phys. Sci (Lond.) 241:20-22.

Jackson, J. G., D. B. Janszen, B. Lönnerdal, E. L. Lien, K. P. Pramuk, and C. F. Kuhlman. 2004. A multinational study of alpha-lactalbumin concentrations in human milk. J. Nutr. Biochem. 15:517-521.

Layman, D. K. 2003. The role of leucine in weight loss diets and glucose homeostasis. J. Nutr. 133:261S-267S.

Lien, E. L. 2003. Infant formulas with increased concentrations of Q-lactalbumin. Am. J. Clin. Nutr. 77:1555S-1558S.

Liu, C., S. Zhai, Q. Zhang, and B. Liu. 2013. Immunochromatography detection of human lactoferrin protein in milk from transgenic cattle. J. AOAC Int. 96:116-120.
Permyakov, E. A., and L. J. Berliner. 2000. Alpha-lactalbumin: Structure and function. FEBS Lett. 473:269-274.

Stephan, O., N. Moller, S. Lehmann, T. Holzhauser, and S. Vieths. 2002. Development and validation of two dipstick type immunoassays for determination of trace amounts of peanut and hazelnut in processed foods. Eur. Food Res. Technol. 215:431-436.

Svensson, M., A. Hakansson, A. K. Mossberg, S. Linse, and C. Svanborg. 2000. Conversion of alpha-lactalbumin to a protein inducing apoptosis. Proc. Natl. Acad. Sci. USA 97:4221-4226.

Tao, C., Q. Zhang, S. Zhai, and B. Liu. 2013. Detection of HbsAg and hATIII genetically modified goats (Caprahircus) by loop-mediated isothermal amplification. Mol. Biol. Rep. 40:6177-6182. http:// dx.doi.org/10.1007/s11033-013-2728-7.

Wang, J., P. Yang, B. Tang, X. Sun, R. Zhang, C. Guo, G. Gong, Y. Liu, R. Li, L. Zhang, Y. Dai, and N. Li. 2008. Expression and characterization of bioactive recombinant human $\alpha$-lactalbumin in the milk of transgenic cloned cows. J. Dairy Sci. 91:4466-4476. http:// dx.doi.org/10.3168/jds.2008-1189.

Zhai, S., C. Liu, Q. Zhang, C. Tao, and B. Liu. 2012. Detection of two exogenous genes in transgenic cattle by loop-mediated isothermal amplification. Transgenic Res. 21:1367-1373. http://dx.doi. org/10.1007/s11248-012-9614-2 